\title{
THE INFLUENCE OF MINERALOGICAL COMPOSITION OF SOIL ON THE CONSOLIDATION COEFFICIENT VALUE
}

\author{
Karina Zabłocka ${ }^{凶}$, Marzena Lendo-Siwicka, Grzegorz Wrzesiński \\ Institute of Civil Engineering, Warsaw University of Life Sciences - SGGW
}

\begin{abstract}
This paper involves the results of oedometric tests carried out on four model samples with different content of expansive clay minerals, subjected to different stresses. The research aimed to determine the impact of consolidation pressure on the consolidation coefficient for cohesive soils with different mineral composition. Main factors influencing correlation between consolidation coefficient and consolidation pressure $\left(C_{v}-p\right)$ trends turned out to be mechanisms controlling changes in soil volume (mechanical or physicochemical), which is different for expansive and non-expansive soils.
\end{abstract}

Key words: consolidation, consolidation coefficient, clay mineralogy, cohesive soils

\section{INTRODUCTION}

The consolidation process is a combination of two phenomena: the permeability, which controls the rate at which the water is expelled out of the soil and thus the rate of settlement at any time, and the compressibility, which controls the evolution of excess pore pressures and thus the duration of the consolidation. During the consolidation process of a saturated clay layer, compressibility and permeability are intimately linked (Shukla, Sivakugan \& Das, 2009). A factor, which characterises the rate of consolidation of a soil, is the consolidation coefficient $\left(C_{v}\right)$ expressed as:

$$
C_{v}=\frac{k}{m_{v} \cdot \gamma_{w}} \cdot 100 \%
$$

where:

$k$ - permeability coefficient,

$m_{v}$ - volume compressibility coefficient,

$\gamma_{w}-$ water unit weight.
Based on Terzaghi and Peck (1967) guidelines with decreasing void ratio (increasing consolidation pressure $-p$ ) both $k$ and $m_{v}$ decrease rapidly, so does the ratio $\left(k / m_{v}\right)$. Thus, we can assume that $C_{v}$ is relatively constant over a wide range of consolidation pressures. Unfortunately, this is not entirely true. Soil consolidation coefficient is not constant but varies with consolidation pressure, which is confirmed by few data available in the literature (Leonards \& Ramiah, 1959; Samarasinghe, Huang \& Drenevich, 1982; Nagase, Kusakabe \& Sing-Fang Wong, 1984; Sridharan, Sivapulliah \& Stalin, 1994). Since importance of this issue was marginalised in the past and not much research was done, the Authors hope to draw more attention to the subject by means of this article.

A conventional consolidation test is conducted over a number of load increments. The number of load increments should cover the stresses range from the initial stress state (in situ) of the soil to the final stress state due to the proposed construction (Skutnik, Lendo-

凶karina_zablocka@sggw.edu.pl 
Zabłocka, K., Lendo-Siwicka, M., Wrzesiński, G. (2020). The influence of mineralogical composition of soil on the consolidation coefficient value. Acta Sci. Pol. Architectura, 19 (3), 83-90. doi: 10.22630/ASPA.2020.19.3.30

-Siwicka \& Garbulewski, 2011). This article presents the results of oedometric tests showing changes in soil consolidation coefficient $\left(C_{v}\right)$ depending on the clay mineralogy.

\section{MATERIAL AND METHODS}

Four samples of model soils were tested: K100B0, K95B05, K90B10, K85B15. Model soils were made of a mixture of powdered clay and distilled water. The components of these soils were two clays - kaolin and bentonite. Kaolin is a soil containing mainly a non-swelling mineral called kaolinite, while bentonite consists mainly of montmorillonite, which is known for its expansive properties. These clays were dried for over $24 \mathrm{~h}$ at the temperature of $105^{\circ} \mathrm{C}$ and then crushed
- X-ray diffraction analysis (XRD);

- thermal analysis.

Model soils (K100B0, K95B05, K90B10, K85B15, K0B100) were characterised as follows: liquid limit (LL) from 42.4 to $501.0 \%$, plastic limit (PL) from 22.8 to $88.7 \%$, plasticity index (PI) from 18.0 to $412.3 \%$, and clay content $(\mathrm{Cl})$ from 23 to $75 \%$. In Figure 1 and Table 2 the physical properties of all tested samples are summarised.

To determine the effect of clay mineralogy and consolidation pressure on consolidation coefficient a number of oedometric studies was conducted. Oedometric tests were carried out in the laboratory of the Department of Geoengineering, Warsaw University of Life Sciences - SGGW (Fig. 2). Conventional one-dimensional consolidation tests were performed on

Table 1. Mineral composition of the tested samples

\begin{tabular}{|c|c|c|c|c|c|c|c|c|c|c|}
\hline \multirow{3}{*}{ Sample } & \multirow{2}{*}{$\begin{array}{c}\text { Clay } \\
\text { minerals } \\
\text { in total }\end{array}$} & \multicolumn{3}{|c|}{ Clay minerals including } & \multirow{2}{*}{ Siderite } & \multirow{2}{*}{ Calcite } & \multirow{2}{*}{ Gypsum } & \multirow{2}{*}{$\begin{array}{c}\text { Organic } \\
\text { matter } \\
\left(\mathrm{I}_{\mathrm{om}}\right)\end{array}$} & \multirow{2}{*}{ Goethite } & \multirow{2}{*}{$\begin{array}{c}\text { Quartz } \\
\text { and } \\
\text { others }\end{array}$} \\
\hline & & montmorillonite & kaolinite & illit & & & & & & \\
\hline & & & & & $\%$ & & & & & \\
\hline K100B0 & 61.6 & - & 61.6 & - & - & - & - & $\begin{array}{c}\text { trace } \\
\text { amount }\end{array}$ & $\begin{array}{l}\text { trace } \\
\text { amount }\end{array}$ & 38.4 \\
\hline K0B100 & 90.1 & $63.1^{\mathrm{a}}$ & - & 27.0 & - & - & - & & 3.0 & 6.9 \\
\hline
\end{tabular}

and combined in appropriate proportions. In this paper, all tested samples of model soils are named in the convention KXXBYY, where XX refers to the percentage of kaolin and $\mathrm{YY}$ to the percentage of bentonite. These contents were determined based on dry weight. For example, the sample called K85B 15 contains $85 \%$ of kaolin and $15 \%$ of bentonite. The reconstituted soil samples used for oedometric tests were prepared so that their humidity was similar - equal to the optimal humidity. Then the soil was compacted in a Proctor Compaction Apparatus, and the samples were cut out with sharpened cylinders.

For the purpose of this article, mineralogical studies of the two main investigated soils (K100B0, K0B100) were carried out. The results are shown in Table 1. The research included:

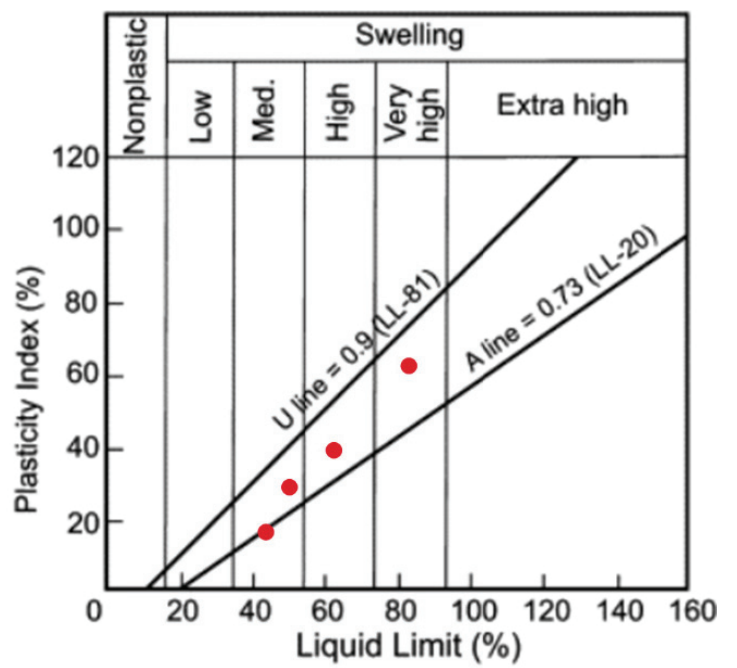

Fig. 1. Casagrande nomogram according to Head (1992) with the test results of soils samples 
Zabłocka, K., Lendo-Siwicka, M., Wrzesiński, G. (2020). The influence of mineralogical composition of soil on the consolidation coefficient value. Acta Sci. Pol. Architectura, 19 (3), 83-90. doi: 10.22630/ASPA.2020.19.3.30

Table 2. Index properties of soil samples

\begin{tabular}{|c|c|c|c|c|c|c|c|c|c|c|c|}
\hline \multirow{4}{*}{ Sample } & \multirow{3}{*}{$\begin{array}{c}\text { Clay } \\
\text { minerals } \\
\text { in total }\end{array}$} & \multicolumn{3}{|c|}{ Clay minerals including } & \multirow{2}{*}{\multicolumn{4}{|c|}{$\begin{array}{l}\text { Fraction content acc. } \\
\text { PN-EN ISO } 14688\end{array}$}} & \multirow{3}{*}{ LL } & \multirow{3}{*}{ PL } & \multirow{3}{*}{ PI } \\
\hline & & \multirow{2}{*}{ montmorillonite } & \multirow{2}{*}{ illit } & \multirow{2}{*}{ kaolinite } & & & & & & & \\
\hline & & & & & $\mathrm{Gr}$ & $\mathrm{Sa}$ & $\mathrm{Si}$ & $\mathrm{Cl}$ & & & \\
\hline & & & & & $\%$ & & & & & & \\
\hline K100B0 & 61.6 & 0 & 0 & 61.6 & - & 5 & 72 & 23 & 42.4 & 24.4 & 18.0 \\
\hline K95B05 & 63.03 & 3.16 & 1.35 & 58.52 & - & 5 & 57 & 38 & 51.7 & 22.9 & 28.8 \\
\hline K90B10 & 64.45 & 6.31 & 2.7 & 55.44 & - & 5 & 56 & 39 & 61.6 & 22.3 & 39.3 \\
\hline K85B15 & 65.88 & 9.47 & 4.05 & 52.36 & - & 5 & 53 & 42 & 85.9 & 22.8 & 63.1 \\
\hline K0B100 & 90.1 & 63.1 & 27.0 & 0 & - & 12 & 13 & 75 & 501.0 & 88.7 & 412.3 \\
\hline
\end{tabular}

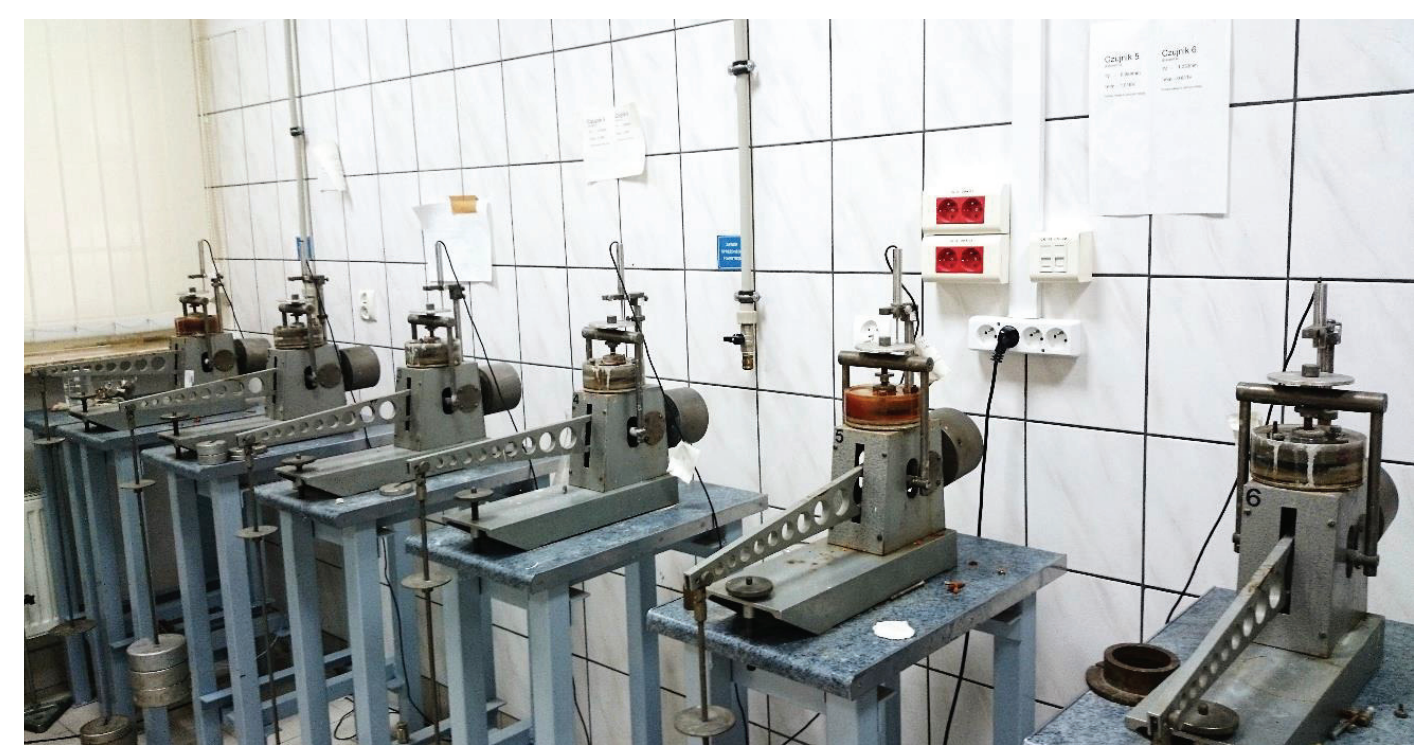

Fig. 2. Oedometers used for clay volume changes tests

50-milimetre diameter and 20-milimetre high soil specimens.

The sample was located in a non-deformable oedometer ring, so changes in the height of the soil sample could only occur in one plane. The samples were subjected to various initial stresses and then flooded with water. They were allowed to swell completely and then subjected to standard stress paths. The applied load increment was the doubling of the loads from the previous stage. The stresses were left until the deformations stabilised. During the test changes in the height of the clay samples were continuously recorded using an electronic displacement sensor connected to a data recorder.

The consolidation curves obtained from the research made it possible to determine the consolidation coefficients. The method presented by Casagrande (1938) was chosen to interpret the curves and the $C_{v}$ were determined for each stage of the load. The determination of the $C_{v}$ by the Casagrande method is described in detail in the available literature (Casagrande, 1938; Lendo \& Skutnik, 2005; Shukla et al., 2009; Malinowska, Bursa, Chmielnicki \& Dziuba, 2013). 


\section{RESULTS AND DISCUSSION}

Figures 3-6 show the variation of consolidation coefficient $\left(C_{v}\right)$ with consolidation pressure $(p)$ for four soil samples differing in the content of expansive clay minerals. Several samples of the same soil were tested, however, they were subjected to different initial stresses.
From data on Figures 3-6 it can be observed that $C_{v}$ is not constant over the $p$ range. Furthermore, the $C_{v}$ variation also depends on a clay mineral type. In soil samples with little to no content of expansive clay minerals like for samples: K100B0, K95B05, $C_{v}$ increases with $p$, while for samples with more that $10 \%$ of bentonite (K90B10, K85B15), $C_{v}$ decreases. Robinson and Allam (1998) observed similar relationships in their

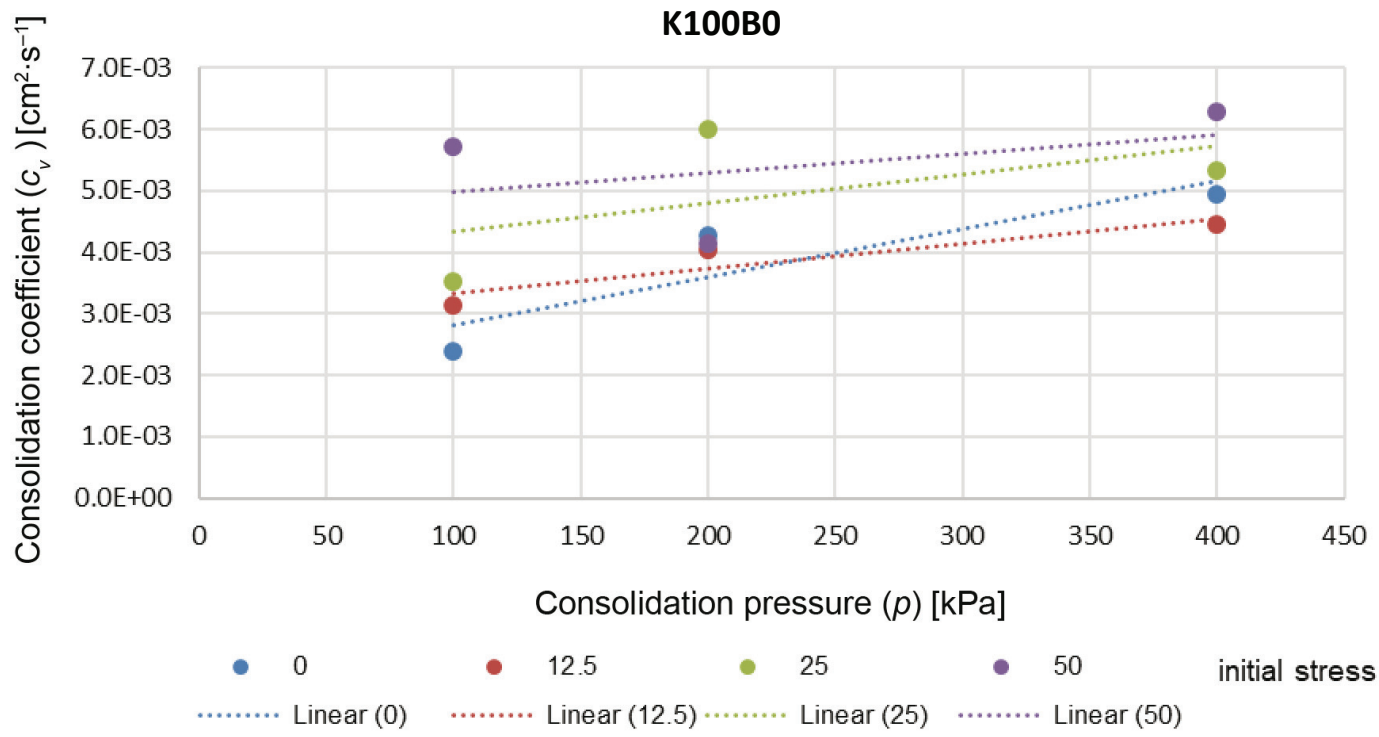

Fig. 3. Variation of consolidation coefficient $\left(C_{v}\right)$ with consolidation pressure $(p)-\mathrm{K} 100 \mathrm{~B} 0$

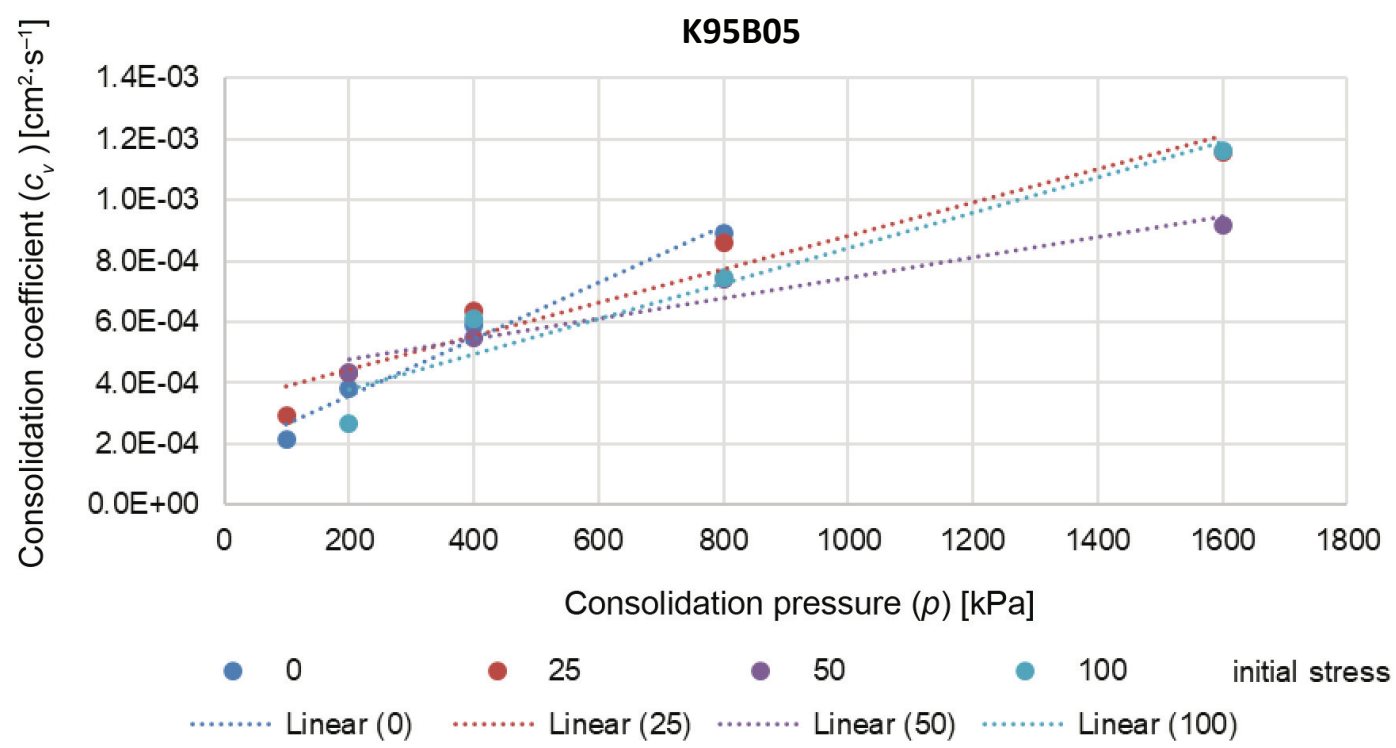

Fig. 4. Variation of consolidation coefficient $\left(C_{v}\right)$ with consolidation pressure $(p)-\mathrm{K} 95 \mathrm{~B} 05$ 


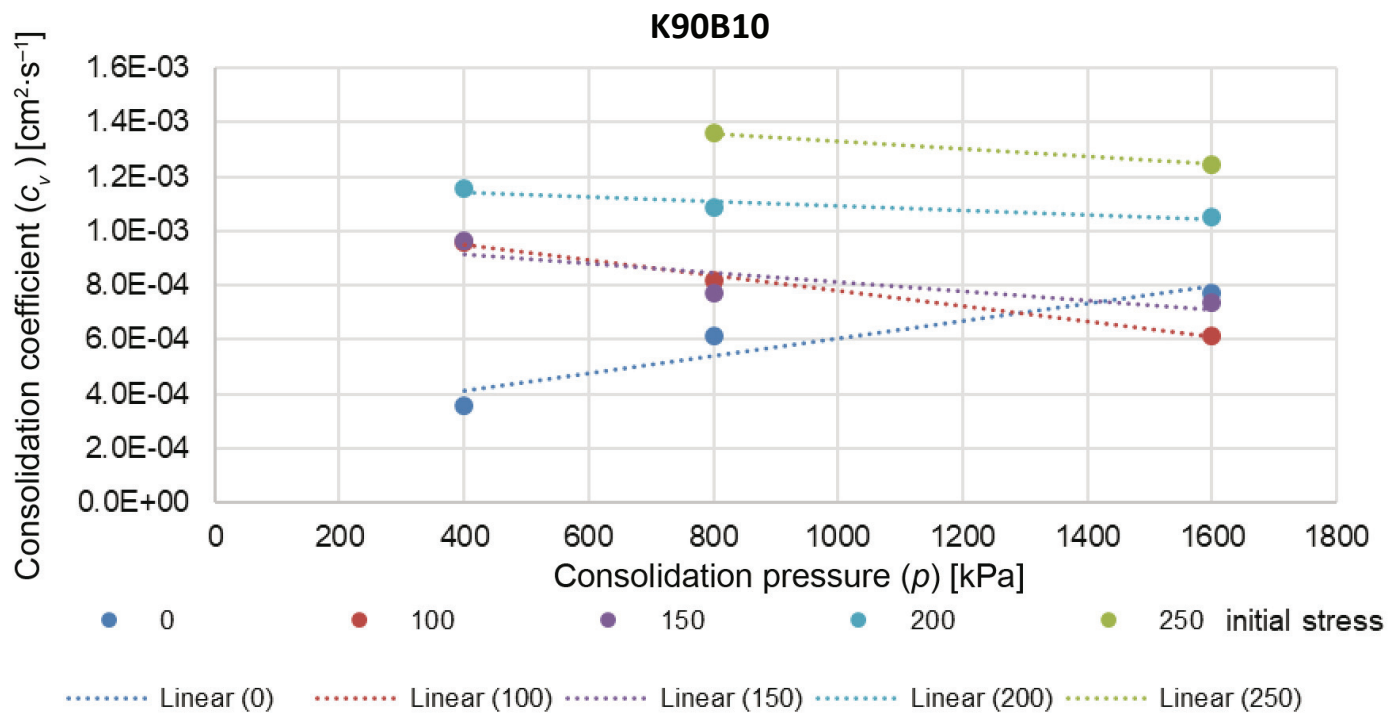

Fig. 5. Variation of consolidation coefficient $\left(C_{v}\right)$ with consolidation pressure $(p)-\mathrm{K} 90 \mathrm{~B} 10$

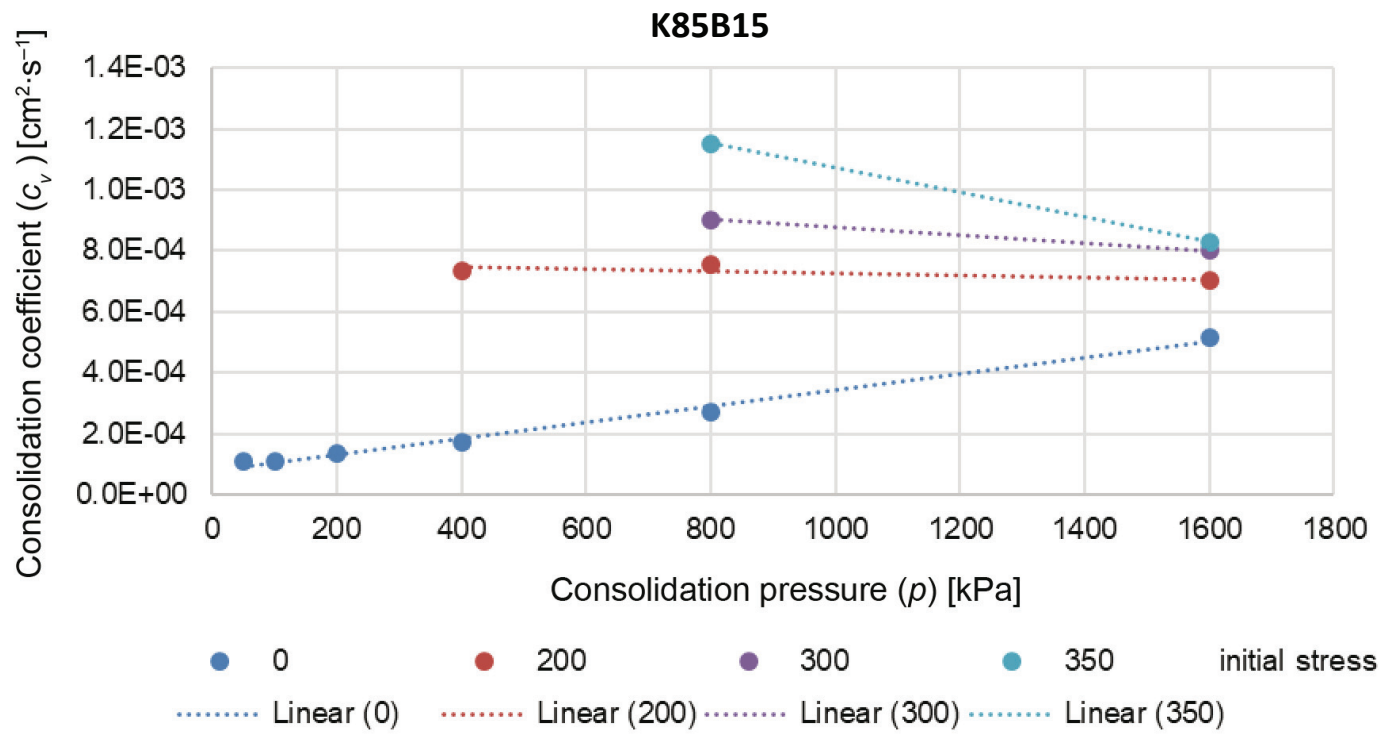

Fig. 6. Variation of consolidation coefficient $\left(C_{v}\right)$ with consolidation pressure $(p)-\mathrm{K} 85 \mathrm{~B} 15$

studies, which were conducted on three types of clay minerals: kaolinite, illite and montmorillonite (Fig. 7).

In order to explain the relations between the $C_{v}$ and the $p$, the mechanisms controlling changes in the volume of cohesive soils should be explained in the first place.

There are two mechanisms controlling changes in the volume of cohesive soils (Rosenqvist, 1955;
Lambe, 1960; Olson \& Mesri, 1970). The first mechanism - in which the compressibility of clay soils is mainly related to shear resistance at the contact points and changes in volume occur due to shear displacement and/or sliding of the particles relative to each other. The second mechanism - in which the compressibility is mainly caused by long-distance electrical repulsive forces. These mechanisms work 


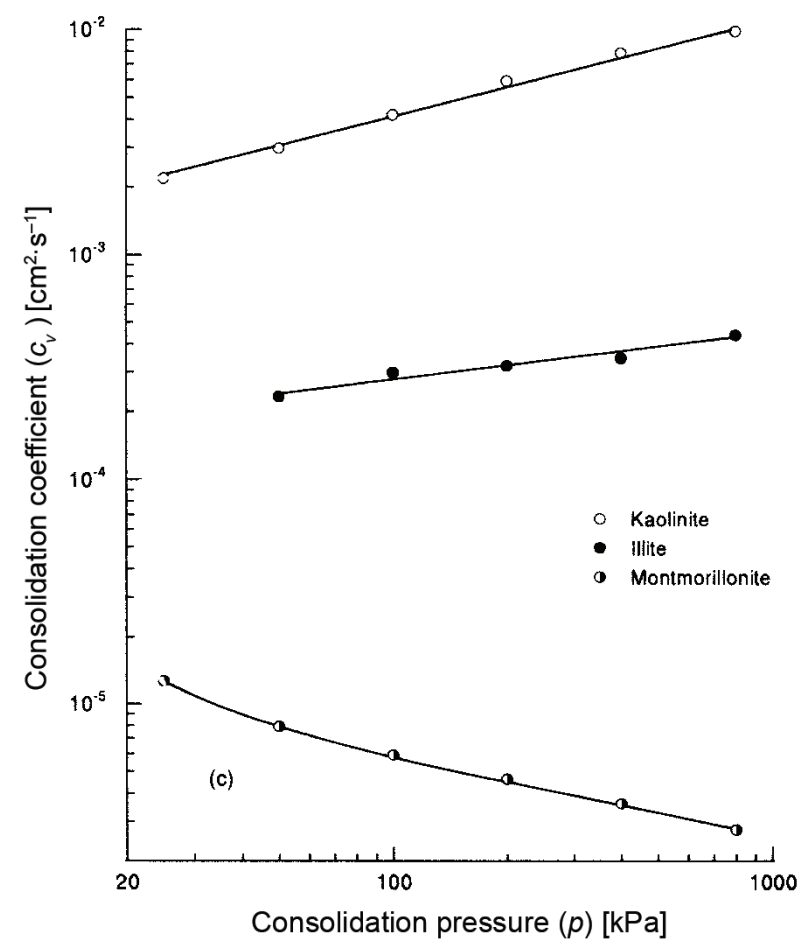

Fig. 7. Variation of consolidation coefficient $\left(C_{v}\right)$ with consolidation pressure $(p)$ for clay minerals with water as the pore fluid (Robinson \& Allam, 1998)

simultaneously, however, published research results (Sridharan \& Rao, 1973) show that the first mechanism plays a dominant role in changes in the volume of non-expansive soils such as kaolin, and the second mechanism in expansive soils with a high content of montmorillonite.

The results of the conducted research show that the consolidation coefficient is not constant but changes with the change of consolidation pressure. In K100B0 and K95B5 soils, the consolidation factor increases with the consolidation stress (Figs. 3, 4). In K85B15 and $\mathrm{K} 90 \mathrm{~B} 10$ soils, i.e. in soils where more than $10 \%$ of bentonite, the consolidation coefficient decreases with stress (Figs. 5, 6). The situation is different only for samples that have been allowed to swell completely - with no initial stress applied. This situation can be explained by the fact that in these samples the distance between the particles increase so much, that intermolecular forces ceased to play the main role and the first mechanism became a dominant factor in consolidation.
Soil consolidation coefficient for sample K100B0 it was much higher than in K85B15. Compressibility is mainly related to the removal of water from clay soils subjected to a load. Water that fills the pores and the spaces between the grains is removed from the soil under the influence of a slight pressure. On the other hand, the removal of water associated with clay minerals requires much higher pressures. Kaolinite mainly contains pore water, and the proportion of water adsorbed on the surface of the mineral plates is small. This is the reason why the already low pressure applied to the sample causes a relatively large decrease in its volume. The decrease in volume begins immediately after the load is applied (Zabłocka, 2019). Both illites and chlorites show similar behaviour. The phenomenon of compressibility of soils containing montmorillonite looks a bit different. This mineral, especially in the sodium form, loses water slowly in the low-pressure range. It is also characterised by relatively slow progress of consolidation over time under a constant load. This is due to the fact that in 
montmorillonite most of the water is intra-crystalline water. Calcium montmorillonite contains less bound water, thus consolidation is faster than that of sodium montmorillonite (Grim, 1960).

\section{CONCLUSIONS}

The results of the study indicate that, in the case of clay minerals, the consolidation coefficient is not constant but varies with consolidation pressure. The influence of consolidation pressure on the consolidation coefficient presented in this paper shows that when the consolidation process is controlled by mechanical factors, as in soils with predominant kaolinite content (K100B0 and K95B05), the consolidation coefficient increases with the consolidation pressure. For soils with a higher montmorillonite content (K90B10 and $\mathrm{K} 85 \mathrm{~B} 15)$, where physicochemical factors affect the consolidation, the consolidation coefficient decreases with increasing consolidation pressure. With the mineral composition of the samples unknown, this relationship can show geotechnical engineers what type of soil they are dealing with, whether the soil is dominated by a mineral such as montmorillonite or kaolinite.

Additionally, for all soil samples, regardless of their mineral composition, a decrease in the consolidation coefficient was observed with the increase in swelling of individual samples.

\section{Authors' contributions}

Conceptualization: K.Z.; methodology: K.Z., M.L.-S.; validation: K.Z. and G.W.; formal analysis: K.Z. and G.W.; investigation: K.Z. and M.L.-S.; resources: K.Z.; data curation: K.Z.; writing - original draft preparation: K.Z.; writing - review and editing: K.Z., M.L.-S., G.W.; visualization: K.Z.; supervision: K.Z. and M.L.-S.; project administration: K.Z.; funding acquisition: K.Z.

All authors have read and agreed to the published version of the manuscript.

\section{REFERENCES}

Casagrande, A. (1938). Notes on Soil Mechanics - First Semester. Cambridge MA: Harvard University.

Grim, R.E. (1960). Clay mineralogy. New York: Mc Graw-Hill Book.
Head, K. H. (1992). Manual of Soil Laboratory Testing. Volume 1: Soil Classification and Compaction Test. 2nd edition. New York: John Wiley and Sons.

Lambe, T. W. (1960). A mechanistic picture of shear strength in clay. In Research Conference on Shear Strength of Cohesive Soils, University of Colorado, Boulder, Colorado, June 1960 (pp. 555-580). New York: American Society of Civil Engineers.

Lendo, M. \& Skutnik, Z. (2005). Badanie współczynnika konsolidacji $\left(c_{v}\right)$ nienasyconych iłów plioceńskich [Test of the coefficient of consolidation $\left(c_{v}\right)$ of unsaturated pliocen clays]. Scientific Review. Engineering and Environmental Sciences, 14 (2), 40-49.

Leonards, G. \& Ramiah, B. K. (1959). Time effects in the consolidation of clays. Papers on Soils 1959 Meetings. ASTM Special Technical Publication, 254, 116-130.

Malinowska, E., Bursa, B., Chmielnicki, P. \& Dziuba, W. (2013). Wyznaczanie współczynnika konsolidacji pionowej i poziomej w słabonośnych gruntach organicznych [Determination of the vertical and horizontal coefficient of consolidation in soft organic soils]. Acta Scientiarum Polonorum. Architectura, 12 (1), 63-74.

Nagase, A., Kusakabe, O. \& Wong, S.-F. (1984). Centrifuge model tests on bearing capacity of clay. Journal of the Geotechnical Engineering, 110 (12), 1749-1765.

Olson, R. E \& Mesri, G. (1970). Mechanisms controlling the compressibility of clays. Journal of the Soil Mechanics and Foundations Division, 96 (6), 1863-1878.

PN-EN ISO 14688. Geotechnical investigation and testing. Identification and classification of soil.

Robinson, R. G., \& Allam, M. M. (1998). Effect of clay mineralogy on coefficient of consolidation. Clays and Clay Minerals, 46 (5), 596-600.

Rosenqvist, I. T. (1955). Investigations in the clay-electrolyte-water system. Oslo: Norwegian Geotechnical Institute.

Samarasinghe, A. M., Huang, Y. H. \& Drnevich, V.P. (1982). Permeability and consolidation of normally consolidated soils. Journal of the Geotechnical Engineering Division, 108 (6), 835-850.

Shukla, S. K., Sivakugan, N. \& Das, B. M. (2009). Methods for determination of the coefficient of consolidation and field observations of time rate of settlement - an overview. International Journal of Geotechnical Engineering, 3 (1), 89-108.

Skutnik, Z., Lendo-Siwicka, M. \& Garbulewski, K. (2011): Assessment of the cv coefficient for unsaturated Warsaw Clay. In E. E. Alonso \& A. Gens (eds.), Proceedings of the Fifth International Conference on Unsaturated Soils, Barcelona, Spain, 6-8 September 2010. Vol. 1 (pp. 371-374). London: Taylor \& Francis Group. 
Sridharan, A. \& Rao, G. V. (1973). Mechanisms controlling volume change of saturated clays and the role of the effective stress concept. Géotechnique, 23 (3), 359-382.

Sridharan, A., Sivapulliah, P. V. \& Stalin, V. K. (1994). Effect of short duration of load increment on the compressibility of soils. Geotechnical Testing Journal, 17 (4), 488-496.
Terzaghi, K. \& Peck, R. B. (1967). Soil mechanics in engineering practice. New York: J. Wiley.

Zabłocka, K. (2019). Wpływ pęcznienia na odkształcenia $i$ wytrzymałość gruntów ilastych [Effect of swelling on the deformation and strength of clay soils] (doctoral thesis). Szkoła Główna Gospodarstwa Wiejskiego w Warszawie, Warszawa.

\section{WPŁYW SKŁADU MINERALNEGO GRUNTÓW NA WSPÓŁCZYNNIK KONSOLIDACJI}

\section{STRESZCZENIE}

W artykule przedstawiono wyniki badań edometrycznych przeprowadzonych na czterech próbkach gruntów modelowych o różnej zawartości ekspansywnych minerałów ilastych poddanych różnym naprężeniom. Celem badań było określenie wpływu naprężenia na współczynnik konsolidacji gruntów spoistych o różnym składzie mineralnym. Głównymi czynnikami wpływającymi na trendy wpółzależności współczynnika konsolidacji z naprężeniem konsolidacji $\left(C_{v}-p\right)$ okazały się mechanizmy kontrolujące zmiany objętości gruntów (mechaniczne lub fizykochemiczne), które są odmienne dla gruntów ekspansywnych i nieekspansywnych.

Słowa kluczowe: konsolidacja, współczynnik konsolidacji, minerały ilaste, grunty spoiste 